\title{
The Influence of Financial Literacy and Financial Behavior to Employee Investment Decision on PT. Angkasa Pura 1 (Persero) Juanda Surabaya
}

\author{
Yuni Sukamdani", Mutiara Rachma Ardhiani, Bambang D.W, Siti Istikhoroh
}

University of PGRI Adi Buana Surabaya, Indonesia

\author{
DOI: $10.36348 /$ sjef.2020.v04i06.009 \\ *Corresponding author: Yuni Sukamdani
}

| Received: 28.05.2020 | Accepted: 04.06.2020 | Published: 12.06.2020

\section{Abstract}

The purpose of this study was to determine the effect of financial literacy and financial behavior on employee investment decision of PT. Angkasa Pura 1 (Persero) Juanda, Surabaya. This research used purposive sampling as a sampling method. 86 employees of PT. Angkasa Pura 1 (Persero) Juanda, Surabaya was chosen as the sample. Data collected by questionnaire and analyzed by multiple linear regression analysis. The results indicate there was a significant influence of financial literacy and financial behavior on employee investment decision on PT. Angkasa Pura 1 (Persero) Juanda, Surabaya. The benefits of research can add insight and information about financial literacy and financial behavior influential in investment decision.

Keywords: Financial literacy, financial behavior, investment decision.

Copyright @ 2020: This is an open-access article distributed under the terms of the Creative Commons Attribution license which permits unrestricted use, distribution, and reproduction in any medium for non-commercial use (NonCommercial, or CC-BY-NC) provided the original author and source are credited.

\section{BACKGROUND}

Human needs increase over the times, so the needs of complex progressing in the economic sector [1]. The increase causes consumerism culture to become higher and become a habit [2].

An example of a high consumption culture today is shopping online. Shopping online makes it easy for someone to fulfill their personal needs or pleasure. This ease creates a consumerist attitude that becomes a habit and makes a person less aware of the importance of saving.

Good financial management is needed in meeting the increasingly complex needs of human life. One of the financial management is investment. Investment is a sacrifice made at the present time in order to get greater profits in the future [3].

For people who will decide to invest, it is important to have extensive knowledge related to finance. The investment decision itself is a policy taken to invest capital in one or more assets or how a person allocates funds in the form of investment, with the aim of earning profits in the future [4].

Someone who will decide to invest, it is important to have financial literacy. Financial literacy is an activity to improve skills, abilities, and knowledge to manage finances better [5]. Financial literacy plays an important role in avoiding cases of investment fraud, which is increasingly prevalent. An example of this case is the investment fraud of the Pandawa Mandiri Savings and Credit Cooperative [6].

Financial literacy is believed to be able to significantly influence investment decisions [2]. The higher the financial literacy owned, the better it will be in deciding to invest. But contrary to research conducted by Fitriarianti [7]. The study concluded that financial literacy did not have a positive effect on investment decisions.

In addition to financial literacy, a person also needs to have financial behavior in an investment decision. Financial behavior is behavior related to the application or practice of finance [8]. Financial behavior is a study of financial behavior that is influenced by a person's psychological condition [9]. Financial behavior is a person's behavior that is influenced by the nature, emotions, preferences and psychological side of their financial application. The influence of financial behavior on investment decision is supported by research carried out by Aminatuzzahra [10] and Fitriarianti [7] which provide a significant effect. 
By looking at the factors of financial literacy and financial behavior on investment decision, researchers examines the effect of financial literacy and financial behavior to state-owned employees, one of which is PT. Angkasa Pura 1 (Persero) Juanda, Surabaya in making investment decision. Tests carried out on employees of PT. Angkasa Pura 1 (Persero) Juanda, Surabaya. When look at the lifestyle of employees, many of them use new cars as their personal transportation. Some are also still pursuing education to a higher level, be it financed by companies, scholarships, or personally. In addition to the income earned from the company, some employees earn other income by doing business.

Based on the description, knowledge about management owned by state-owned employees is interesting to study, especially for employees who plan investments. By paying attention to the description above, researchers want to prove that financial literacy and financial behavior influence the employee's investment decisions of PT. Angkasa Pura 1 (Persero) Juanda, Surabaya.

\section{METHOD}

This study used 86 employees as population of PT. Angkasa Pura 1 (Persero) Juanda, Surabaya. The sampling technique used was purposive sampling. The type of data in this study is quantitative. Data sources are primary data types. Data collection techniques using a questionnaire instrument.

The instrument test was carried out with a validity and reliability test. Data analysis uses multiple linear regression. Stages of multiple linear regression analysis through the classical assumption test consisting of normality test, multicollinearity test, heterokedasticity test and autocorrelation test.

The variables in this study are dependent and independent variables. Independent variables include financial literacy and financial behavior. While the investment decision variable is the dependent variable.

\section{RESULTS}

\section{Instrument Test Results}

Based on the Table-1, it can be seen that all variables are valid. This is evidenced by each pearson correlation value more than 0.30 .
Table-1: Validity Test

\begin{tabular}{|c|c|c|}
\hline Variable & Question & $\begin{array}{l}\text { Pearson } \\
\text { Correalation }\end{array}$ \\
\hline \multirow[t]{10}{*}{ Financial Literacy } & 1 & 0,554 \\
\hline & 2 & 0,683 \\
\hline & 3 & 0,590 \\
\hline & 4 & 0,755 \\
\hline & 5 & 0,498 \\
\hline & 6 & 0,518 \\
\hline & 7 & 0,669 \\
\hline & 8 & 0,785 \\
\hline & 9 & 0,697 \\
\hline & 10 & 0,469 \\
\hline \multirow[t]{10}{*}{ Financial Behavior } & 1 & 0,407 \\
\hline & 2 & 0,549 \\
\hline & 3 & 0,658 \\
\hline & 4 & 0,712 \\
\hline & 5 & 0,610 \\
\hline & 6 & 0,751 \\
\hline & 7 & 0,526 \\
\hline & 8 & 0,531 \\
\hline & 9 & 0,552 \\
\hline & 10 & 0,605 \\
\hline \multirow{6}{*}{$\begin{array}{l}\text { Investment } \\
\text { Decision }\end{array}$} & 1 & 0,711 \\
\hline & 2 & 0,693 \\
\hline & 3 & 0,724 \\
\hline & 4 & 0,697 \\
\hline & 5 & 0,608 \\
\hline & 6 & 0,679 \\
\hline
\end{tabular}

Table-2 shows the Cronbach alpha value on each statement item in each variable is more than 0.60 . Then the data can be said to be reliable.

Table-2: Reliability Test

\begin{tabular}{|l|l|}
\hline Variable & Cronbach Alpha \\
\hline Financial Literacy & 0,723 \\
\hline Financial Behavior & 0,784 \\
\hline Investment Decision & 0,752 \\
\hline
\end{tabular}

\section{Classical Assumption Test \\ Normality test}

Normality test results with the One-Sample K$\mathrm{S}$ have a significance value of 0.78 . It indicates that the research data is normally distributed.

\section{Multicollinearity Test}

Table-3 shows the financial literacy and financial behavior have the same tolerance value that is 0.542 (more than 0.10 ) and the VIF value on both variables has the same value that is 1.811 (less than 10.00). This proves there is no multicollinearity on the model. 
Table-3: Multicollinearity Test

\begin{tabular}{|l|l|l|}
\hline Variable & Tolerance & VIF \\
\hline Financial Literacy & 0,542 & 1,811 \\
\hline Financial Behavior & 0,542 & 1,811 \\
\hline
\end{tabular}

\section{Heteroscedasticity Test}

Table-4 shows that the data do not occur symptoms of heteroscedasticity. This is evidenced by the value of significance more than 0.05 .

Table-4: Heteroscedasticity Test

\begin{tabular}{|l|l|}
\hline Variable & Sig. (2-tailed) \\
\hline Financial Literacy & 0,715 \\
\hline Financial Behavior & 0,653 \\
\hline
\end{tabular}

\section{Autocorrelation Test}

The Durbin-Watson value in Table-5 is between 1.55-2.46, which is 2.106. This proves that there is no autocorrelation.

Table-5: Autocorrelation Test

\begin{tabular}{|l|}
\hline Durbin-Watson \\
\hline 2,106 \\
\hline
\end{tabular}

\section{Hypothesis Test}

Based on the hypothesis test, the results are obtained:

1. The employee investment decision of PT. Angkasa Pura 1 (Persero) Juanda, Surabaya influenced by financial literacy with t-value 2,969 and sig. 0.012.

2. The employee investment decision of PT. Angkasa Pura 1 (Persero) Juanda, Surabaya influenced by financial behavior with t-value 3.098 and sig. 0.004 .

Table-6: Hypothesis Test

\begin{tabular}{|l|l|l|l|l|}
\hline Model & B & $\begin{array}{l}\text { Std. } \\
\text { Error }\end{array}$ & t & Sig. \\
\hline Constant & 8,415 & 1,496 & 5,622 & 0,000 \\
\hline $\begin{array}{l}\text { Financial } \\
\text { Literacy }\end{array}$ & 0,463 & 0,172 & 2,696 & 0,012 \\
\hline $\begin{array}{l}\text { Financial } \\
\text { Behavior }\end{array}$ & 0,470 & 0,152 & 3,098 & 0,004 \\
\hline
\end{tabular}

\section{DISCUSSION}

Based on the research that has been done, the results are obtained:

1. There is a significant influence of Financial Literacy on employee investment decision of PT. Angkasa Pura 1 (Persero) Juanda, Surabaya. Knowledge of financial instruments which include insurance, investment, and savings, debt, and credit will make one consider what are the possible risks that occur when deciding to invest. A good understanding of financial knowledge will prevent an increasingly widespread case of investment fraud. The better skills, abilities, and knowledge about financial management, so when deciding to invest, you can minimize or even reduce the likelihood of risks.
Having higher financial literacy will motivate you to invest more.

This result is supported by Putri \& Rahyuda [2] which provides the same results.

2. There is a significant influence of Financial Behavior on the employee investment decision of PT. Angkasa Pura 1 (Persero) Juanda, Surabaya. A person's behavior in managing finances involves the nature, emotional, and other psychological side that causes how will decide investment. If good financial management habits are carried out, it will make someone reconsider when deciding on investments. When someone is able to control their attitudes and emotions in managing their finances, then when investing will also be able to control their activities in investing. The person must be consistent with the decision he has taken, so as to avoid losses or risks that will occur. Research conducted by Fitriarianti [7] and Aminatuzzahra [10] supports the results of this study.

\section{CONCLUSION}

This research proves the influence of financial literacy on employee investment decision of PT. Angkasa Pura 1 (Persero) Juanda, Surabaya. The higher level of employee's financial literacy, they will be in making investment decision better.

This research also proves the influence of financial behavior on employee investment decision of PT. Angkasa Pura 1 (Persero) Juanda, Surabaya. The better behavior of employees in financial management, they will also make better investment decision.

\section{REFERENCES}

1. Rizkiana, Y. P., \& Kartini. (2017). Analisis Tingkat Financial Literacy dan Financial Behavior Mahasiswa S-1 Fakultas Ekonomi Universitas Islam Indonesia. 7(1):76-99.

2. Putri, N., Made, D. R., \& Rahyuda, H. (2017). Pengaruh Tingkat Financial Litercay dan Faktor Sosiodemografi Terhadap Perilku Keputusan Invetasi Individu. E-Jurnal Ekonomi dan Bisnis Universitas Udayana, 6(9).

3. Haming, M., \& Basalamah. (2010). Studi Kelayakan Investasi Proyek dan Bisnis. Jakarta: Bumi Aksara.

4. Wulandari, D. A. (2014). Studi Experienced Regret, Risk Tolerance, Overconfidance dan Risk Perception pada Pengambilan Keputusan Investasi Dosen Ekonomi. Journal of Business and Banking.

5. OJK (Otoritas Jasa Keuangan). 2013. Edukasi dan Perlindungan Konsumen (https://www.ojk.go.id/id/kanal/edukasi-danperlindungan-konsumen/Pages/LiterasiKeuangan.aspx, diakses tanggal 27 November 2018).

6. Detik News. 2017. Begini Modus Nuryanto dalam Penipuan Investasi Pandawa Grup. Tersedia di https://news.detik.com/berita/d-3428257/begini- 
modus-nuryanto-dalam-penipuan-investasipandawa-group.

7. Fitriarianti, B. (2018). Pengaruh Literasi Keuangan, Perilaku Keuangan dan Pendapatan Terhadap Keputusan Berinvestasi. Seminar Nasional 1 Universitas Pamulang.

8. Bestari S., \& Nidar, S. R. (2012). Personal Literacy Among University Students (Case Study at Padjajaran University Students, Bandung, Indonesia). World Journal of Social Sciences. 2(4):162-171.
9. Shefrin, H. (2000). Beyond Greed and Fear: Understanding Behavioral Finance and Psychology of Investing. Harvard Business School Press.

10. Aminatuzzahra. (2014). Persepsi Pengaruh Pengetahuan Keuangan, Sikap Keuangan, Sosial Demografi Terhadap Perilaku Keuangan Dalam Pengambilan Keputusan Investasi Individu (Studi Kasus Pada Mahasiswa Magister Manajemen Universitas Diponegoro). Jurnal Bisnis dan Strategi. 23(2):70-96. 